\title{
PENDIDIKAN GIZI UNTUK KESEHATAN MENTAL SELAMA PANDEMI PADA FORUM ILMIAH ABDIMAS ESA UNGGUL
}

\author{
Nadiyah, Khayatul Afiyah, Risa Martiana, Rizkita Windhiyaningrum, Rofifa Khairi, \\ Anggrita Salsabila Ramadhia \\ Fakultas Ilmu-ilmu Kesehatan, Universitas Esa Unggul, Jakarta \\ KP Pluis No 3 Grogol Utara Kebayoran Lama, Jakarta Selatan 12210, \\ nadiyah@esaunggul.ac.id
}

\begin{abstract}
The impact of Coronavirus Disease (Covid)-19 pandemic occurs on various dimensions of human life including mental health. People often experience anxiety, stress, depression and other forms of mental disorders during this pandemic. The purpose of this community empowermentwas to provide education about nutritional condition and its relation to mental health due to the Covid-19 pandemic to increasethe awareness of the role of nutrition for mental healthduring this pandemic. The pandemic causes increased eating and snacking frequency and body weight, decreased physical activity level and increased anxiety and depression due to social isolation during the pandemic. This activity was carried out by the nutrition lecturer of the Esa Unggul University involving 5 college students and 1 psychology lecturer. Through the planning and socialization stages, the core implementation of this activity was held via Forum Ilmiah Abdimas on 5 November 2020 from 1.00 to 4.00 p.m and was attended by 60 participants from various institutions. As part of the evaluation, the post-test results showed that the average score among the participants was above the median value thenindicated the material of this community service was quite well received by the participants. The results of the participant satisfaction pollingdenoted that the presentation was very satisfying.
\end{abstract}

Keywords : pandemic, nutrition, stress

\begin{abstract}
Abstrak
Pandemi Covid (Coronavirus Disease)-19 memberikan efek dalam berbagai dimensi kehidupan manusiatermasukkesehatan mental. Dari rasa cemas, stress, depresi dan bentuk gangguan mental lainnya kerap dialami orang pada masa pandemi. Tujuan dari kegiatan ini adalah memberikan pendidikan mengenai kondisi gizi dan kaitannya dengan kesehatan mental akibat pandemi Covid-19 untuk membangun kesadaran masyarakat mengenai pentingnya peran gizi dalam menjaga kesehatan mental selama masa pandemi Covid-19. Pandemi menyebabkan peningkatan frekuensi makan, snacking, berat badan, penurunan tingkat aktivitas fisik dan meningkatnya risiko anxiety dan depresi karena isolasi sosial selama pandemi. Kegiatan ini dilakukan oleh dosen Program Studi Ilmu Gizi Universitas Esa Unggul dengan melibatkan 5 mahasiswa dan 1 dosen psikologi dalam pelaksanaan kegiatan. Setelah melalui tahap perencanaan dan sosialisasi, kegiatan inti pengabdian masyarakat ini diselenggarakan melalui Forum Ilmiah Abdimas yang diadakan secara daring pada tanggal 5 November 2020 pukul 13.00 hingga 16.00 WIB dan diikuti oleh sebanyak 60 peserta umum dari berbagai instansi. Sebagai bagian dari tahapan evaluasi, hasil post-test peserta kegiatan abdimas menunjukkan, skor rata-rata di atas nilai median dan dapat dikatakan bahwa secara umum materi abdimas dapat diterima dengan cukup baik oleh peserta. Hasil polling kepuasan peserta menunjukkan bahwa penyampaian materi sangat memuaskan.
\end{abstract}

Kata kunci : pandemi, gizi, stres

\section{Pendahuluan}

Menurut Undang-Undang No. 36 tahun 2009, kesehatan adalah keadaan sehat baik secara fisik, mental, spiritual, maupunsosial yang memungkinkan semua orang untuk hidup produktif secara sosial dan ekonomis. Menurut perhitungan beban penyakit pada tahun 2017, beberapa jenis gangguan jiwa yang diprediski dialami oleh penduduk di Indonesia diantaranya adalah gagguan depresi, cemas, skizofrenia, bipolar, gangguan perilaku, autis, gangguan perilaku makan, cacat intelektual, Attention Deficit Hyperactivity Disorder (ADHD). Dalam masa tiga dekade (1990-2017), terjadi perubahan pola penyakit mental, dimana yang mengalami peningkatan DALYs diantaranya skizofrenia, bipolar, autis, dan gangguan perilau makan. Gangguan depresi tetap menduduki urutan pertama dalam tiga dekade. Gangguan depresi dapat dialami oleh semua kelompok usia. Hasil Riskesdas 2018 menunjukkan gangguan depresi sudah mulai terjadi sejak rentang usia remaja (15-24 tahun), dengan prevalensi $6,2 \%$. Pola prevalensi depresi semakin meningkat seiring dengan peningkatan usia, tertinggi pada umur 75+ tahun sebesar 8,9\%, 65-74 tahun sebesar 8,0\% dan 55-64 tahunsebesar 6,5\% (Kementerian Kesehatan RI, 2019). 
Saatini, dunia termasuk Indonesia terjangkit wabah Covid(Coronavirus Disease). Pandemi Covid (Coronavirus Disease)-19 memberikan efek dalam berbagai dimensi kehidupan manusia. Dari sisi kesehatan, hingga ekonomi, dan tentunya kejiwaan seseorang. Dari rasa cemas, stress, depresi dan bentuk gangguan mental lainnya kerap dialami orang pada masa pandemi. Bukan hanya cemas tertular virus, namun juga stress dan depresi akibat terjadinya resesi ekonomi akibat pandemi. Baik lansia, dewasa maupun remaja kerap kali merasa tertekan. Beberapa berita melaporkan terdapat siswa bunuh diri karena merasa tertekan dengan Pendidikan Jarak Jauh (PJJ) yang terasa sulit diakses baginya. Angka perceraian dilaporkan meningkat akibat pandemi. Anxiety (rasa cemas) meningkat baik karena khawatir dengan kondisi kesehatan ataupun ancaman putusnya pekerjaan dan sebagainya.Tekanan hidup yang semakin rumit, antara lain tekanan sosial, ekonomi, pekerjaan, tingkat kemacetan, dan sebagainya seringkali memicu terjadinya stres. Stres berpotensi memicu depresi yang berkelanjutan. Di tengah meningkatnya tekanan hidup, jumlah kasus gangguan mental terus bertambah hingga berdampak pada penambahan beban negara dan penurunan produktivitas jangka panjang.

Gangguan mental emosional adalah gangguan yang dapat dialami semua orang pada keadaan tertentu. Gangguan ini dapat berlanjut menjadi gangguan yang lebih serius apabila tidak berhasil ditanggulangi. Peningkatan proporsi gangguan mental pada data yang didapatkan (Kemenkes RI, 2018) cukup signifikan jika dibandingkan dengan Riskesdas 2013, naik dari $1,7 \%$ menjadi $7 \%$. Gangguan emosional ini ditemukan lebih tinggi pada penduduk perkotaan dibandingkan penduduk di perdesaan. Gangguan mental yang paling umum adalah depresi, gangguan bipolar dan skizofrenia.

Menurut prediksi WHO, depresi akan menjadi penyebab penyakit kedua terbesar di seluruh dunia (Murray \& Lopez, 1996). Stres psikososial yang berlanjut terus menerus tanpa diselingi dengan periode pemulihan yang mencukupi dapat menimbulkan gejala-gejala depresi dan mengakibatkan menurunnya daya tahan tubuh, rentan terhadap infeksi, meningkatkan risiko alergi, burnout syndrom (keletihan emosional, depersonalisasi, berkurangnya perhargaan pada diri sendiri), berat badan berlebih, gangguan saluran pencernaan, hipertensi, penyakit jantung koroner, migrain dan kanker (Grober, 2012).

Depresi adalah gangguan yang terkait dengan gejala utama seperti meningkatnya kesedihan dan kecemasan, kehilangan nafsu makan, suasana hati yang tertekan, serta hilangnya minat dengan kegiatan yang menyenangkan. Jika tidak ada intervensi yang tepat waktu, gangguan ini dapat menyebabkan berbagai konsekuensi. Pasien yang menderita depresi menunjukkan kecenderungan bunuh diri. Stres adalah keadaaan fisik yang terganggu sebagai respon terhadap stimulus non spesifik melalui reaksi fisik, seperti peningkatan tekanan darah, berkeringat, atau takikardia. Beban berlebih yang terus menerus disertai dengan perangsang stress yang parah (keributan konflik selama tujuh hari seminggu) tanpa diselingi dengan periode pemulihan yang mencukupi dapat menyebabkan distress (stress negatif).

Stres hingga depresi merupakan masalah psikologi yang biasanya ditangani dengan konseling ataupun secara medis dengan obat antidepresan, namun ada hal lain yang turut berperan terhadap timbulnya stres yaitu asupan gizi. Banyak orang menyadari hubungan antara gizi dengan penyakit fisik, namun masih sedikit yang menyadari adanya hubungan gizi dengan depresi. Gizi memiliki peran penting terhadap terjadinya depresi, hingga durasi dan tingkat keparahannya. Ketidakseimbangan gizi berhubungan dengan risiko mudah atau tidaknya seseorang mengalami depresi(Beardsley, 2009).

Depresi umumnya menyebabkan penderitanya cenderung memiliki nafsu makan yang buruk, melewatkan jam makan, dan dominan memilih makanan dan minuman yang manis. Salah satu faktor yang sering mendasari terjadinya stres adalah buruknya pengendalian kadar gula dalam darah. Gejala-gejala gangguan pengendalian kadar gula dalam darah diantaranya adalah kelelahan, mudah marah, pusing, sulit tidur, konsentrasi yang buruk dan depresi(Sathyanarayana Rao et al., 2008).

Tujuan dari kegiatan ini adalah memberikan pendidikan mengenai kondisi gizi dan kaitannya dengan kesehatan mental akibat pandemi Covid-19 untuk membangun kesadaran masyarakat mengenai pentingnya peran gizi dalam menjaga kesehatan mental selama masa pandemiCovid-19.

\section{Metode Pelaksanaan}

Kegiatan pengabdian masyarakat ini diselenggarakan melalui Forum Ilmiah Abdimas yang diadakan secara daring pada tanggal 5 November 2020 pukul 13.00 hingga 16.00 WIB. Kegiatan ini dilakukan bersama dengan ahli dari bidang psikologi untuk memberikan materi mengenai efek pandemi terhadap kesehatan mental dengan tujuan agar dapat memberikan knowledge lebih dalam dari sisi psikologi mengenai gambaran kesehatan mental selama pandemi. Jumlah peserta dalam kegiatan ini sebanyak 60 orang, terdiri dari masyarakat umum, tenaga medis dan nonmedis,dosen, mahasiswa dan civitas akademik lainnya. 
Persiapan dan pelaksanaan kegiatan abdimas ini disesuaikan dengan kondisi pandemi yang sedang berlangsung. Perencanaan kegiatan meliputi persiapan data-data terkait isi materi abdimas menggunakan referensi-referensi ter-update seputar pandemi, kesehatan mental dan gizi. Disamping itu, dilakukan koordinasi dan kerjasama dengan dosen dari bidang psikologi untuk mendukung kegiatan abdimas dari sisi penguatan topik psikologi. Kerjasama juga dilakukan dengan pihak Lembaga Penelitian dan Pengabdian Masyarakat (LPPM) Universitas Esa Unggul sebagai owner/pemilik dari wadah Forum Ilmiah Abdimas. Sebagai bagian dari persiapan kegiatan, rangkuman materi sebanyak 5 halaman disampaikan kepada pihak LPPM, kemudian dilanjutkan dengan kelengkapan materi berupan power point presentation dan post-test.

Sosialisasi kegiatan Forum Ilmiah Abdimas dilakukan oleh pihak LPPM melalui email undangan, official facebook LPPM, dan whatsapp group 1 minggu sebelum kegiatan berlangsung. Setiap peserta diwajibkan mengisi link pendaftaran disamping sebagai salah satu syarat untuk memperoleh sertifikat kegiatan.

Pelaksanaan kegiatan dimulai dengan menyanyikan lagu Indonesia Raya dan Mars Universitas Esa Unggul, dilanjutkan dengan sambutan dari wakil rektor bidang Riset, Pengambangan dan Inovasi, lalu dari ketua LPPM. Materi pertama mengenai kesehatan mental selama pandemi disampaikan oleh Ibu YuliAzmi Rozali dari program studi psikologi. Materi abdimas kedua diberikan oleh Ibu Nadiyah dari program studi gizi mengenai gizi dan kesehatan mental selama pandemi. Kegiatan dilanjutkan dengan sesi tanya jawab kepada kedua narasumber kegiatan abdimas yang dipandu oleh moderator. Setelah sesi tanya jawab selesai, peserta diwajibkan mengisi post-test untuk mengkaji efektivitas kegiatan abdimas dan mengisi polling survey sebagai bahan evaluasi kegiatan Forum Ilmiah Abdimas dan sebagai salah satu syarat memperoleh sertifikat bagi peserta kegiatan. Setelah perencanaan dan pelaksanaan serta evaluasi di atas, laporan kegiatan abdimas dibuat dan disampaikan untuk kemudian dilanjutkan dengan publikasi pada Jurnal Abdimas Universitas Esa Unggul.

\section{Hasil dan Pembahasan}

Kegiatan ini dilakukan oleh dosen Program Studi Ilmu Gizi Universitas Esa Unggul dengan melibatkan 5 mahasiswa dalam persiapan kegiatan dan melibatkan 1 dosen psikologi dalam pelaksanaan kegiatan. Kegiatan ini diikuti oleh sebanyak 60 peserta dari berbagai instansi. Sekitar 90\% berasal dari institusi Pendidikan Tinggi dari Banjarmasin, Jakarta, dan Palu. Selebihnya berasal dari instansi Puskesmas. Dilihat dari sisi status pekerjaan peserta cukup beragam, sebanyak $60 \%$ adalah mahasiswa, hampir 30\% adalah dosen, selebihnya adalah ahli gizi, koki dan marketer.

Berdasarkan hasil analisis situasi terkait perilaku gizi dan kesehatan mental selama pandemi menggunakan data hasil penelitian dengan metode yang valid, diperoleh bahwa terjadi peningkatan frekuensi makan serta snacking pada orang dewasa saat pandemi. Peningkatan frekuensi makan dan snacking terjadi signifikan berdasarkan status gizi. Frekuensi paling meningkat ditemukan pada kelompok obesitas $(55,3 \%)$, kedua paling tinggi adalah pada kelompok overweight (48,8\%) selanjutnya pada kelompok underweight (40,7\%). Peningkatan frekuensi makan paling rendah pada kelompok dengan status gizi normal $(30,6 \%)$. Peningkatan frekuensi makan dan snacking ditemukan signifikan terjadi pada kelompok usia 3445 tahun dan kelompok usia $>45$ tahun. Terdapat penambahan berat badan, penurunan aktivitas fisik, peningkatan anxiety dan depresi karena isolasi sosial selama pandemi. Diketahui tidak ada hubungan antara penambahan berat badan dan tingkat pendidikan, tempat tinggal, atau status pekerjaan (Di Renzo et al., 2020; Sidor \& Rzymski, 2020; Survey et al., 2020).

Materi kegiatan abdimas yang disampaikan diawali dengan pemaparan fenomena-fenomena yang terjadi pada perilaku gizi dan kesehatan mental selama pandemi. Pemaparan secara komprehensif disampaikan dari sisi data dan konsekuensikonsekunsi ilmiah terhadap kesehatan yang dinilai dari sisi sosial, ekonomi, mental, spiritual dan fisik. Selanjutnya materi inti disampaikan mengenai mekanis mehubungan gizi dan kesehatan mental, respon metabolisme gizi dalam tubuh terhadap kondisi stress yang terjadi, keseimbangan gizi yang penting dipertahankan untuk kesehatan mental, pengaruh asupan gizi terhadap risiko stress, dan pengaruh stress terhadap asupan gizi. Terakhir materi disampaikan tentang proses pemasakan yang mampu mempertahankan kandungan zat gizi agar tidak banyak yang hilang.

Berikut adalah beberapa contoh materi yang disampaikan:

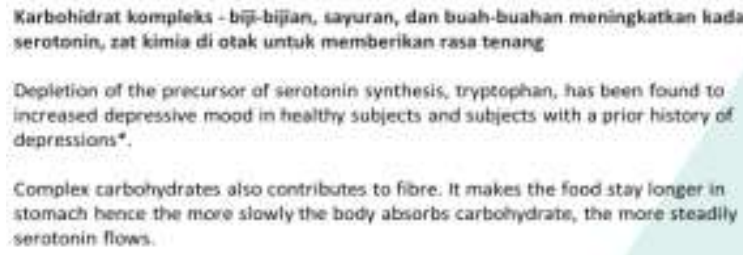
stomach beace the more slowly the body absorbs carbohydrate, the more steadil serotonin flows. 


\section{OMEGA 3 FATTY ACIDS}

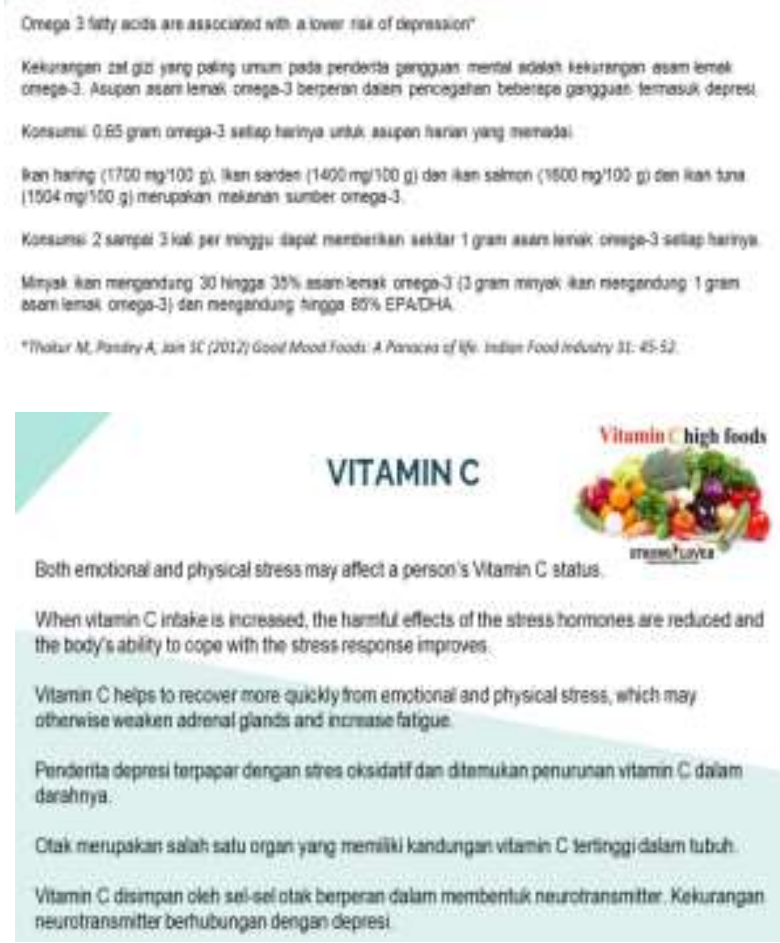

Setelah sesi penyampaian materi abdimas, kegiatan dilanjutkan dengan sesi tanyajawab, pertanyaan yang datang dari peserta cukup beragam dari sisi teori hingga aplikasinya sehari-hari. Selanjutnya peserta diwajibkan mengisi post-test. Adapun rincian soal-soal dalam post-test dapat dilihat dalam tabel 1 berikut. Post-test ini bertujuan untuk mengukur tingkat pemahaman peserta terhadap materi abdimas yang manfaatnya dapat menjadi bahan evaluasi bagi pelakasana kegiatan abdimas.

Tabel 1.

Post-test

\begin{tabular}{|c|c|c|}
\hline So. & Seal & Jawaban \\
\hline 1. & $\begin{array}{l}\text { Masa pandemi cenderung menberikan } \\
\text { dampak perubahas pada forole } \\
\text { seseorang, diantaranya : }\end{array}$ & $\begin{array}{l}\text { a. Peningkatan ftekuensi makan. } \\
\text { macking, dan berat badan } \\
\text { b. Penuranas aktivitas fisik das } \\
\text { peningkatan stress paikososial } \\
\text { c. Semua benar }\end{array}$ \\
\hline 2. & $\begin{array}{l}\text { Dalam masa karantina efek Pasdemi. } \\
\text { peningkatan berat badan terjadi lebilh } \\
\text { signifikan pada kelompok: }\end{array}$ & $\begin{array}{l}\text { A. Usia diatas } 35 \text { tahuan } \\
\text { b. Onnneight dan obesitas } \\
\text { c. Semua benar }\end{array}$ \\
\hline 3. & $\begin{array}{l}\text { Di bawah ini yang dapat meningkatkas } \\
\text { serotonin (2ait kinia di otak yang } \\
\text { menberikan rasa tenang) adalals: }\end{array}$ & $\begin{array}{l}\text { a. Kasbotidrat kotapleks } \\
\text { b. Katbobidrat kedertana } \\
\text { c. Lemak }\end{array}$ \\
\hline 4. & $\begin{array}{l}\text { Otak merupakan salah satu orgas yang } \\
\text { memiliki kandungan-+. tertinge dalan } \\
\text { tobuh. }\end{array}$ & $\begin{array}{l}\text { A. Viramin B } \\
\text { b. Vitamin C } \\
\text { c. Vitamin K }\end{array}$ \\
\hline 5. & $\begin{array}{l}\text { Bvah berikut kaya akas senyas:a } \\
\text { triptofin, seryawa yag diguakas } \\
\text { ustuk sintesis serotonin di otak, yaitu : }\end{array}$ & $\begin{array}{l}\text { a. Semangka } \\
\text { b. Pisang } \\
\text { c. Jeruk }\end{array}$ \\
\hline
\end{tabular}

Hasil post-test dapat dilihat pada grafik 1 dibawah. Dari grafik tersebut tampak bahwa soal nomor 5 berupa materi terkait buah tinggi kadar triptofan yang paling banyak dijawab dengan benar $(91 \%)$, karena memang pemateri memberikan contoh berulang-berulang penggunaan buah tersebut dalam menu sehari-hari sehingga cenderung mudah diingat oleh peserta. Soal nomor 4 berupa konsep/teori biokimia mengenai kandungan vitamin tertinggi pada otak tampak paling sulit dijawab dengan benar $(31 \%)$ oleh peserta. Hal ini disebabkan karena tidak adanya pengulangan ataupun penekanan pada teori tersebut. Maksud dan tujuan dimunculkan pertanyaan tersebut agar menjadi landasan ilmiah bagi peserta tentang pentingnya asupan vitamin $\mathrm{C}$ dalam mempertahankan kerja sistem saraf di otak. Selebihnya untuk soal nomor 1 hingga 3 , peserta umumnya cenderung dapat menjawab dengan benar, walaupun pada soal nomor 2 dan 3 hanya sekitar $60 \%$ peserta yang dapat menjawab dengan benar. Kegiatan abdimas ini dilakukan secara daring sehingga fokus dan perhatian peserta terdestruksi dengan kegiatan atau kondisi di sekitarnya. Skor terbesar yang mungkin dapat diperoleh dalam post test adalah 5, dimana jawaban yang benar mendapat skor 1 dan bila salah mendapat skor 0 , sehingga secara keseluruhan, ratarata skor peserta adalah 3,13 dengan standar deviasi sebesar 0,84. Rata-rata ini sedikit di atas nilai median, sehingga dapat dikatakan materi abdimas dapat diterima peserta dengan cukup baik.

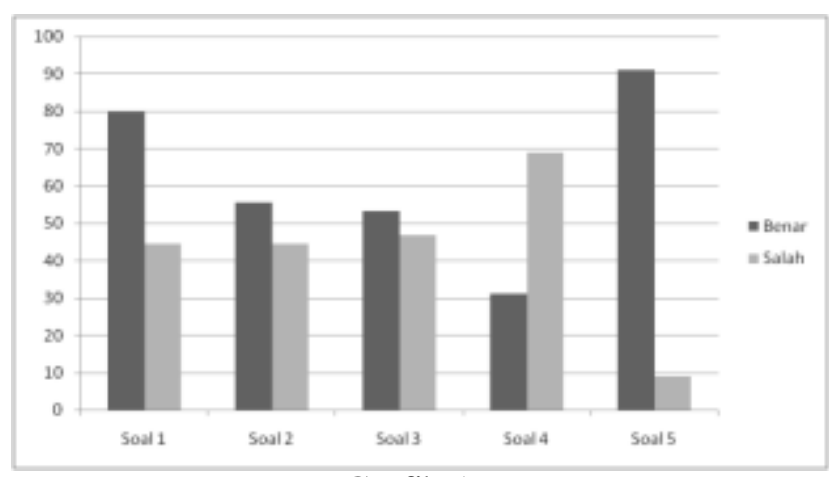

Grafik 1.

Persentase jawaban benar dan salah pada masingmasing soal post-test

Setelah peserta menyelesaikan post-test, peserta diwajibkan untuk mengisi polling sebagai bahan evaluasi dan rencana perbaikan kegiatan abdimas kedepan. Isi polling dapat dilihat pada grafik 2 di bawah. Hampir separuh (41\%) dari keseluruhan peserta merasa sangat tertarik dengan acara. Sebagian besar peserta merasa puas dengan keseluruhan acara $(65,5 \%)$ dan merasa telah sesuai dengan harapan $(86,2 \%)$. Dari sisi penyampaian materi, sebagian besar $(62,1 \%)$ peserta merasa sangat puas dengan materi yang diberikan dalam kegiatan abdimas Gizi dan Kesehatan Mental. Tingkat kepuasan peserta tertinggi adalah pada sisi penyampaian materi, selanjutnya pada keseluruhan acara. 


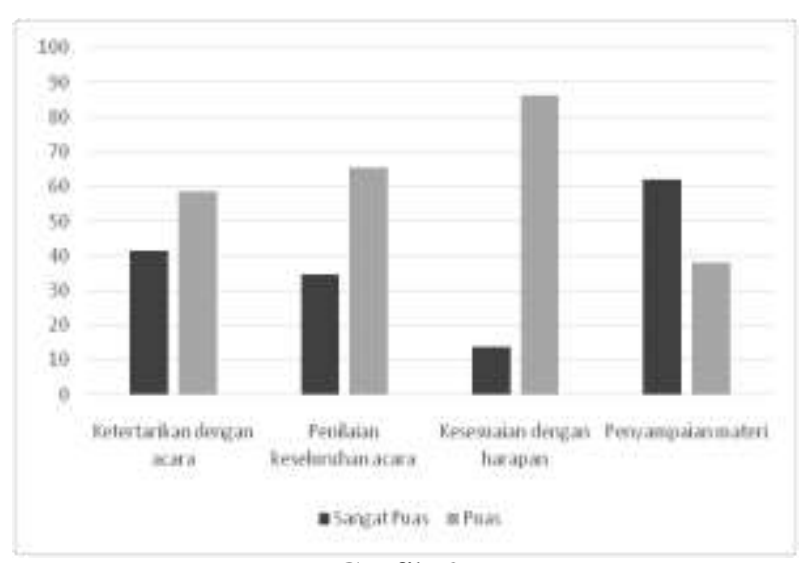

Grafik 2.

Hasil polling kepuasan peserta kegiatan abdimas

\section{Kesimpulan}

Pandemi menyebabkan peningkatan frekuensi makan, snacking, berat badan, penurunan tingkat aktivitas fisik dan meningkatnya risiko anxiety dan depresi karena isolasi sosial selama pandemi. Kegiatan abdimas ini mampu menambah pengetahuan dan pengalaman peserta mengenai dampak pandemi terhadap gizi dan kesehatan mental serta prinsip asuhan gizi terkait. Hasil post-test menunjukkan, skor rata-rata di atas nilai median dan dapat dikatakan bahwa secara umum materi abdimas dapat diterima dengan cukup baik oleh peserta. Hasil polling kepuasan peserta menunjukkan penyampaian materisangat memuaskan.

\section{Daftar Pustaka}

Beardsley, B. (2009). Depression and Nutrition. http://www.healingwell.com/LIBRARY/dep ression/beardsley/.asp.

Di Renzo, L., Gualtieri, P., Pivari, F., Soldati, L., Attinà, A., Cinelli, G., Cinelli, G., Leggeri, C., Caparello, G., Barrea, L., Scerbo, F., Esposito, E., \& De Lorenzo, A. (2020). Eating habits and lifestyle changes during COVID-19 lockdown: An Italian survey. Journal of Translational Medicine, 18(1), 115. https $/ /$ doi.org/10.1186/s12967-02002399-5

Grober, U. (2012). Mikronutrien: Penyelarasan Metabolik, Pencegahan, dan Terapi. EGC.

Kemenkes

RI.

(2018)

Laporan_Nasional_RKD2018_FINAL.pdf.

In Badan Penelitian dan Pengembangan

Kesehatan (p. 198).

http://labdata.litbang.kemkes.go.id/images/d

ownload/laporan/RKD/2018/Laporan_Nasio

nal_RKD2018_FINAL.pdf
Kementerian Kesehatan RI. (2019). Situasi Kesehatan Jiwa di Indonesia. In Infodatin. https://pusdatin.kemkes.go.id/resources/dow nload/pusdatin/infodatin/InfoDatinKesehatan-Jiwa.pdf

Murray, C. J. ., \& Lopez, A. D. (1996). Global Burden of Disease and Injur Y Series the Global Burden of Disease. Oms, 1-46.

Sathyanarayana Rao, T., Asha, M., Ramesh, B., \& Jagannatha Rao, K. (2008). Understanding nutrition, depression and mental illnesses. Indian Journal of Psychiatry, 50(2), 77. https://doi.org/10.4103/0019-5545.42391

Sidor, A., \& Rzymski, P. (2020). Dietary choices and habits during COVID-19 lockdown: Experience from Poland. Nutrients, 12(6), 1-13. https://doi.org/10.3390/nu12061657

Survey, E. I. O., Ammar, A., Brach, M., Trabelsi, K., Chtourou, H., Boukhris, O., Masmoudi, L., Bouaziz, B., Bentlage, E., How, D., Ahmed, M., Müller, P., Müller, N., Aloui, A., \& Hammouda, O. (2020). E ff ects of COVID-19 Home Confinement on Eating Behaviour and Physical Activity: Results of the ECLB-COVID19 International Online Survey. Nutrients, 12, 1583-1596. 